\title{
Induction of the synthesis of the pregnancy-specific protein p70 in the endometrium by intramuscular injection of recombinant bovine interferon- $\alpha_{I} 1$ in nonpregnant ewes
}

\author{
H. Francis, D. H. Keisler and R. M. Roberts* \\ Department of Animal Sciences, University of Missouri, Columbia, MO 65211, USA
}

\begin{abstract}
Summary. We examined the effect of recombinant bovine interferon- $\alpha_{1} 1$ (rboIFN- $\left.\alpha_{1} 1\right)$ or recombinant bovine trophoblast protein-1 (rbTP-1) on protein synthesis by endometrial explants from Day-13 cyclic ewes and studied the ability of rboIFN- $\alpha_{1} 1$ injected i.m. to influence subsequent protein scretion by endometrial tissue explants.

In Expt 1 , ewes were injected with either $2 \mathrm{mg}$ rboIFN- $\alpha_{1} 1$ or vehicle alone at $12-\mathrm{h}$ intervals beginning on Day 11 of the oestrous cycle and ending on the morning of Day $13 ; 8 \mathrm{~h}$ after the last injection, ewes were hysterectomized and endometrial explant cultures were prepared. Explants were cultured for $24 \mathrm{~h}$ in leucine-deficient medium supplemented with $250 \mu \mathrm{Ci} \mathrm{L}-\left[{ }^{3} \mathrm{H}\right]$ leucine per culture. For Expt 2, additional explants were prepared from Expt 1 controls. Explants were cultured in the presence of 0,20 or $200 \mathrm{ng} / \mathrm{ml}$ of either rboIFN- $\alpha_{1} 1$ or $\mathrm{rbTP}-1$ for $24 \mathrm{~h}$ in leucine-deficient medium supplemented with $250 \mu \mathrm{Ci} \mathrm{L}-\left[{ }^{3} \mathrm{H}\right]$ leucine per culture. Secreted proteins were analysed by two-dimensional electrophoresis and fluorography. There was a marked enhancement of a $70 \mathrm{kDa}$ acidic protein, p70, in explants cultured in the presence of rboIFN$\alpha_{1} 1$ or rbTP-1. This polypeptide is a product of the gravid uterine horn from Day 14 to Day 20 of pregnancy and is a useful marker of the action of interferon- $\alpha$ (IFN- $\alpha$ ) on endometrium. Enhanced production of p70 also occurred in ewes injected i.m. with rboIFN- $\alpha_{1} 1$. These results are consistent with the hypothesis that injected rboIFN- $\alpha_{1} 1$ exerts its effects on such variables as interoestrus interval and maternal recognition of pregnancy by actions on the uterus.
\end{abstract}

Keywords: cattle; interferon- $\alpha$; pregnancy; protein; sheep; trophoblast

\section{Introduction}

The trophoblast interferons bovine trophoblast protein-1 (bTP-1) and ovine trophoblast protein-1 (oTP-1) are considered to play a key role in maintaining the functionality of the corpus luteum during early pregnancy in cattle and sheep, respectively (Roberts, 1989; Roberts et al., 1990a). These proteins are first secreted in large amounts by the trophoblast just before the corpus luteum would normally begin to regress during a normal oestrous cycle (Godkin et al., 1982; Bartol et al., 1985; Hansen et al., 1985). Their interaction with the endometrium appears to attenuate the frequency and magnitude of pulsatile prostaglandin F-2 $\alpha$ release by the uterus (Bazer et al., 1986; Vallet et al., 1987), even though in ewes the total quantity of PGF-2 $\alpha$ leaving the uterus may increase during pregnancy (Zarco et al., 1988). Because of this change in uterine PGF-2 $\alpha$ dynamics, oTP-1 and bTP-1 have generally been considered to affect the uterus and not the ovary or some other extrauterine site. There has been no evidence to suggest that oTP-1 injected into the uterine lumen is able to escape and enter the maternal blood circulation (Godkin et al., 1984).

\footnotetext{
*Reprint requests.
} 
It was of interest, therefore, that recombinant bovine interferon- $\alpha_{1} 1$ (rboIFN- $\alpha_{1} 1$ ) injected intramuscularly into ewes was able to extend the interoestrus interval almost as effectively as when it was introduced directly into the uterus (Plante et al., 1989). Even more intriguing was that intramuscular injections of this same interferon (IFN) twice a day into ewes between Days 11 and 18 after mating significantly increased their chances of maintaining a successful pregnancy (Nephew et al., 1990; Roberts et al., 1990b; Schalue-Francis et al., 1991). In these pregnancy studies it was assumed that the injected IFN had supplemented the action of endogenous oTP-1 produced by the conceptus and had enhanced maternal recognition of pregnancy. However, there was no evidence that the biological effects of the injected IFN were manifested through its action on the endometrium. Schalue-Francis et al. (1991) were not able to detect antiviral activity in the uterine flushings of cyclic ewes injected with IFN. In the present study, we tested whether injected IFN influenced protein synthesis by the endometrium. We examined whether a $70000 M_{\mathrm{r}}$ acidic protein (p70) was induced by the treatment. This protein is produced by endometrial tissue explants and cultured epithelial cells from cyclic ewes when exposed to oTP-l or a human IFN- $\alpha_{1}$ (Godkin et al., 1984; Vallet et al., 1987; Salamonsen et al., 1988; Silcox et al., 1988). It is also a product of endometrial tissue derived from Day 14,16 and 17 pregnant ewes, but not of cultured explants from cyclic ewes at equivalent stages of their oestrous cycles (Sharif et al., 1989). It appears, therefore, to be pregnancy-specific as well as a sensitive marker of IFN- $\alpha$ action on the endometrium.

\section{Materials and Methods}

\section{Materials}

The rboIFN- $\alpha_{1} 1$ (Capon et al., 1985) was provided by Ciba Geigy Ltd (Basel, Switzerland) as a sterile-formulated, succinate-buffered lyophilizate containing mannitol. The placebo consisted of the same formulation minus rboIFN$\alpha_{1} 1$. The dried substances were reconstituted with sterile, pyrogen-free distilled water. Recombinant bTP-1 was produced in our laboratory (Klemann et al., 1990). Material for injection was prepared by using the placebo as diluent. L- $\left[3,4,5-{ }^{3} \mathrm{H}\right]$ leucine (specific activity $153 \mathrm{Ci} / \mathrm{mmol}$ ) was purchased from New England Nuclear, Boston, MA, USA. Tissue culture supplies were obtained from Fisher Scientific, St Louis, MO, USA. Material used for medium preparation and two-dimensional polyacrylamide gel electrophoresis and fluorography were obtained as described by Sharif et al. (1989).

\section{Medium}

Eagle's minimum essential medium (MEM) was prepared deficient in L-leucine according to the method of Sharif et al. (1989). In addition, the medium was buffered with $20 \mathrm{~mm}$ Hepes buffer and contained $0 \cdot 10 \mathrm{~g}$ sodium pyruvate $/ \mathrm{l}$.

\section{Animals}

Sexually mature cross-bred ewes were maintained on open pasture and checked twice a day for oestrus with a vasectomized ram. On Day 8 or 9 of the oestrous cycle, the animals were placed in individual pens in a confinement facility for the duration of the experiment.

\section{Endometrial explant cultures}

Ewes were anaesthetized with xylazine/ketamine and maintained with halothane on closed-system anaesthesia. Uteri were exposed via midventral laparotomy. Uterine horns were flushed with $25 \mathrm{ml}$ Dulbecco's phosphate-buffered saline. Ewes were then hysterectomized and the uterus was placed on ice prior to further processing. Endometrium was stripped from underlying tissues from the tip of each horn to the centre of the uterine body. The endometrium was sectioned into small slices $(2-3 \mathrm{~mm})$ and rinsed twice with culture medium prior to placement into culture.

Individual cultures of $500 \mathrm{mg}$ wet tissue weight in $10 \mathrm{ml}$ culture medium were placed in $100 \times 20 \mathrm{~mm}$ Petri dishes. Culture medium was supplemented with $250 \mu \mathrm{Ci}$ of $\mathrm{L}-\left[{ }^{3} \mathrm{H}\right] \mathrm{leucine}$. Tissue samples were cultured for $24 \mathrm{~h}$ at $37^{\circ} \mathrm{C}$ in an atmosphere of $55 \% \mathrm{~N}_{2}, 45 \% \mathrm{O}_{2}$ and $5 \% \mathrm{CO}_{2}$ by volume, on a rocking platform. Cultures were terminated by immediate placement on ice, followed by centrifugation at $3000 \mathrm{~g}$ for $20 \mathrm{~min}$ at $4^{\circ} \mathrm{C}$. Supernatant solutions were extensively dialysed against distilled water containing $0.1 \mathrm{~mm}$ phenylmethane sulphonyl fluoride and $0.02 \% \mathrm{NaN}_{3}$. Cultures were frozen at $-20^{\circ} \mathrm{C}$ until processed.

\section{Protein analysis}

Secreted proteins were evaluated by two-dimensional electrophoresis as follows: aliquots of culture medium containing approximately $8 \times 10^{5} \mathrm{~d}$.p.m. (nondialysable counts) were dried by means of a Savant Speed-Vac and 
Table 1. Effect of intramuscular injection of recombinant bovine interferon- $\alpha_{1} 1$ (rboIFN- $\left.\alpha_{1} 1\right)$ on the subsequent ability of ewe endometrial explants to incorporate $\mathrm{L}-\left[{ }^{3} \mathrm{H}\right]$ leucine into proteins released into the culture medium

\begin{tabular}{|c|c|c|c|}
\hline Treatment & $\begin{array}{l}\text { Source of } \\
\text { endometrial } \\
\text { tissue }\end{array}$ & $\begin{array}{l}\text { Protein } \\
\text { in medium* } \\
(\mathrm{mg} / \mathrm{ml})\end{array}$ & $\begin{array}{c}\text { Radioactivity } \\
\text { incorporated } \\
\left(\text { d.p.m. } \times 10^{-7}\right)\end{array}$ \\
\hline Vehicle & $\begin{array}{l}\text { Pooled tissue from } \\
\text { both uterine horns }\end{array}$ & $0.74 \pm 0.02(4)$ & $1 \cdot 89 \pm 0.35(5)$ \\
\hline rboIFN- $\alpha_{1} 1$ & Ipsilateral horn & $0.93 \pm 0.02$ & $1.95 \pm 0.39(4)$ \\
\hline rboIFN- $\alpha_{1} 1$ & Contralateral horn & $0.91 \pm 0.01(4)$ & $1.61 \pm 0.30(4)$ \\
\hline
\end{tabular}

Endometrial explants were cultured, as described in the Methods, from Day 13 oestrus ewes injected with either vehicle $(n=5)$ or rbolFN- $\alpha_{1} 1$.

*Data are average values \pm s.e.m. (with numbers of ewes in parentheses). No significant differences were observed between treatments or between tissues from the uterine horns ipsi- or contralateral to the corpus luteum $(P>0 \cdot 1)$. None of the ewes used had bilateral corpora lutea.

reconstituted in $55 \mu$ l solubilization buffer for isoelectric focusing in the first dimension. After second-dimension electrophoretic separation on a $12.5 \%$ polyacrylamide gel containing sodium dodecyl sulphate (Roberts et al., 1984), the proteins were stained with Coomassie Brilliant Blue R-250 and treated with Enhance (New England Nuclear, Boston, MA, USA) prior to fluorography. Fluorographs were prepared on Kodak XAR-5 radiographic film and exposed for 13 days.

\section{Experiment 1}

Cyclic ewes were injected with either $2 \mathrm{mg}$ rbolFN- $\alpha_{1} 1 \quad(n=5)$ or vehicle alone (control; $\left.n=4\right)$ at 12-h intervals beginning on Day 11 of the oestrous cycle and ending on the morning of Day 13, i.e. five injections per ewe. Hysterectomies were performed $\sim 8 \mathrm{~h}$ after the last injection. Explant cultures were prepared in triplicate $(500 \mathrm{mg}$ each). Cultures were prepared from each uterine horn of ewes treated with rboIFN- $\alpha_{1} 1$ and evaluated separately. Tissue from control ewes was pooled for evaluation. Secreted proteins were analysed by two-dimensional electrophoresis.

\section{Experiment 2}

Endometrium from cyclic Day 13 ewes ( $n=4$; Expt 1 controls) was partitioned into five treatment groups: control, $20 \mathrm{ng} / \mathrm{ml}$ or $200 \mathrm{ng} / \mathrm{ml}$ rbolFN- $\alpha_{1} 1$ or 20 or $200 \mathrm{ng} / \mathrm{ml} \mathrm{rbTP}-1$ added per culture. Triplicate cultures were prepared for each treatment group and cultured as indicated. Proteins in culture medium were analysed as in Expt 1.

\section{Statistical procedures}

The data for incorporation of $\mathrm{L}-\left[{ }^{3} \mathrm{H}\right]$ leucine into nondialysable materials in the culture medium were evaluated by analysis of variance with treatment, treatment dose and tissue source (contralateral vs. ipsilateral uterine horn) (SAS, 1985).

\section{Results}

\section{Experiment 1}

Endometrial explants from ewes injected with rboIFN- $\alpha_{1} 1$ incorporated similar amounts of L$\left[{ }^{3} \mathrm{H}\right]$ leucine into nondiffusible products as ewes receiving vehicle (controls) (Table 1). No significant differences were observed between tissues obtained from the uterine horns ipsilateral or contralateral to the ovary bearing the corpus luteum $(P>0 \cdot 1)$. The medium from these cultures contained similar amounts of protein. Most of this protein can probably be accounted for as nonradioactive serum components that leached out of the tissue during incubation. For example, the large clear area noted in the upper central areas of the fluorographs in Figs 1 and 2 represents 

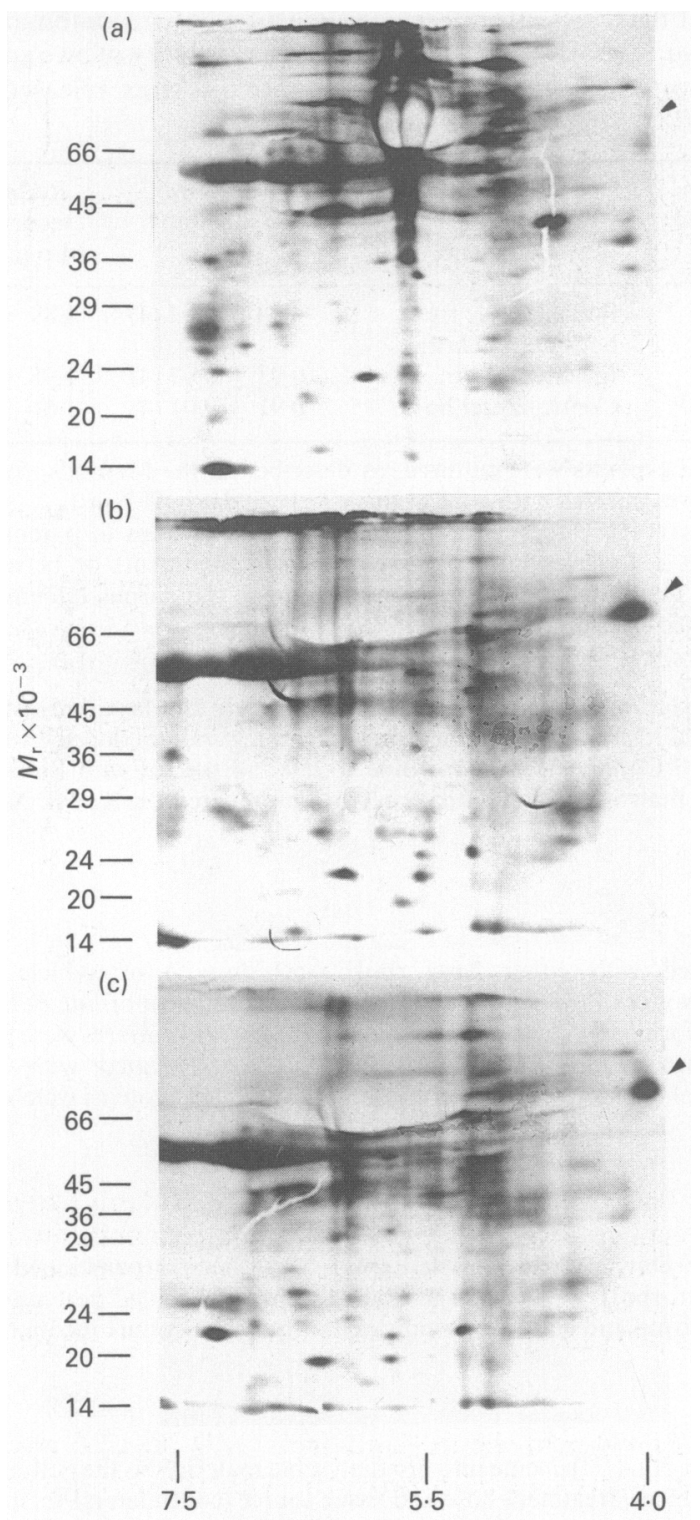

pI of polypeptides in first dimension

Fig. 1. Comparison of polypeptide production of radioactive polypeptides released by cultured endometrial explants derived from Day 13 cyclic ewes receiving vehicle (control) or recombinant bovine interferon- $\alpha_{1} l$ (rbolFN- $\left.\alpha_{1} 1\right)$ i.m. Plates are representative fluorographs showing two-dimensional polyacrylamide gels loaded with equivalent amounts of radioactivity and exposed to X-ray film for the same period: (a) from a control animal, (b) from the ipsilateral and (c) contralateral horns of a ewe injected i.m. with rboIFN- $\alpha_{1} 1$. The p70 protein is enhanced in both horns, as indicated by arrows.

unlabelled serum albumin. Its presence, and that of other less abundant serum proteins, invariably causes some distortion of the pattern of labelled products on two-dimensional gels.

The p70 protein was clearly evident in all cultures derived from ewes that had been injected with rboIFN- $\alpha_{1} 1$ (Fig. 1). It was invariably absent in the control (vehicle-injected) group. The amount of 
(a)

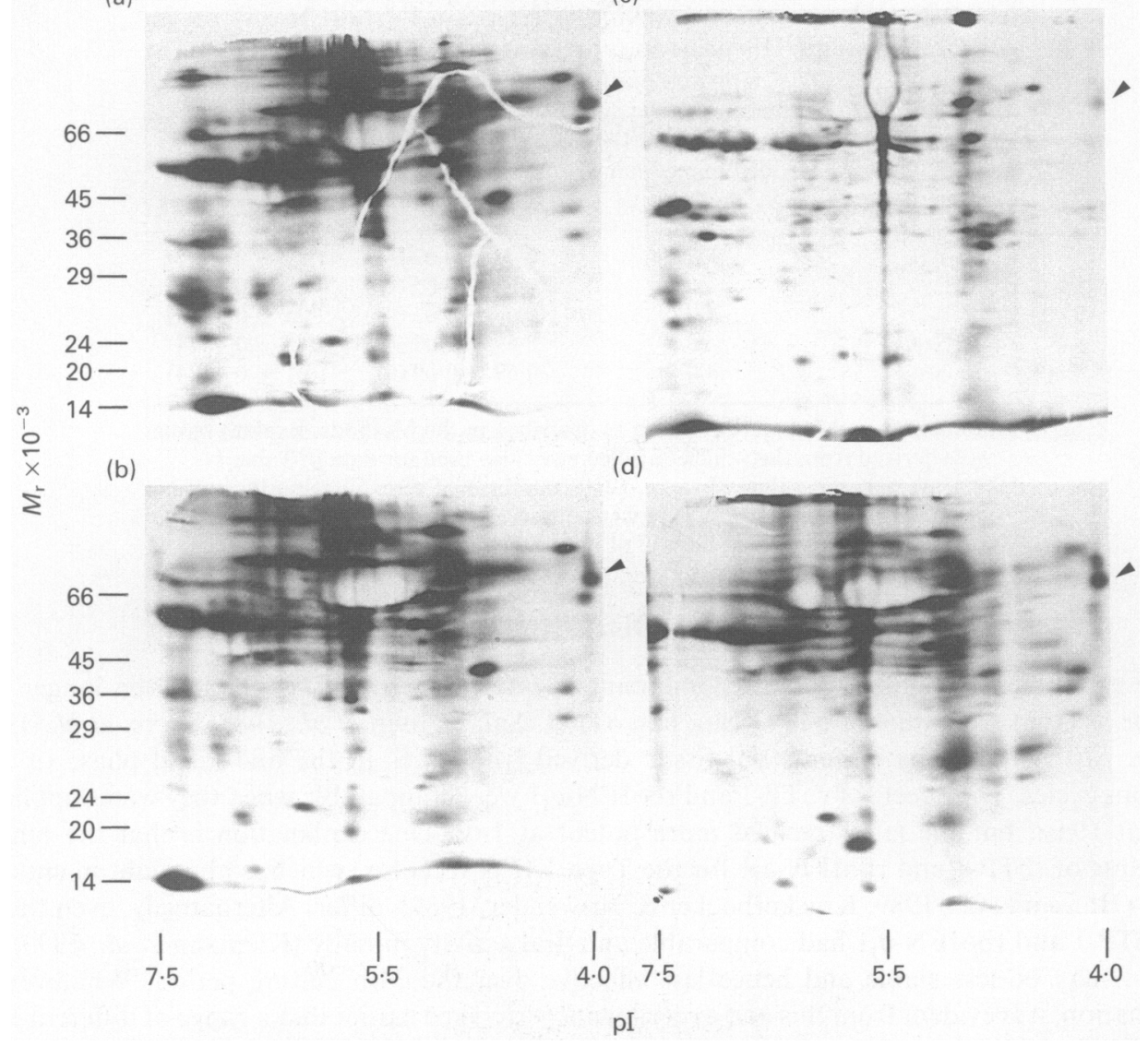

Fig. 2. Comparison of polypeptide production by cultured explants derived from control Day 13 ewe endometrium incubated with (a) 20 or (b) $200 \mathrm{ng} / \mathrm{ml}$ recombinant bovine interferon- $\alpha_{1} 1$ (rboIFN- $\alpha_{1} 1$ ); (c) 20 or (d) $200 \mathrm{ng} / \mathrm{ml}$ recombinant bovine trophoblast protein-1 (rbTP-1). Plates are representative fluorographs of two-dimensional polyacrylamide gels. The arrows indicate location of the $\mathrm{p} 70$ protein, which is apparent in all four cultures.

p70 produced was always greater in the explants from IFN-injected ewes than in cultures from placebo ewes where the explants had been provided with rboIFN- $a_{1} 1$ only for the $24-h$ culture period (Fig. 2).

\section{Experiment 2}

Endometrial explants from Day 13 cyclic ewes incorporated $1.89 \pm 0.35 \times 10^{7}$ d.p.m. of radiolabel from $\mathrm{L}-\left[{ }^{3} \mathrm{H}\right] \mathrm{leucine}$ into nondiffusible components in the culture medium during a $24-\mathrm{h}$ period (Table 2). This control value was not significantly different from values noted for tissues that had been cultured in the presence of either rbTP-1 or rboIFN- $\alpha_{1} 1(P>0 \cdot 1)$. Endometrial tissue from a Day 13 cyclic ewe only produced increased amounts of $p 70$ if it had been cultured in presence of either bTP-1 or rboIFN- $\alpha_{1} 1$ (Fig. 2). Both kinds of IFN were equally effective in inducing p70 when they were supplied at $200 \mathrm{ng} / \mathrm{ml}(\sim 10 \mathrm{nM})$ (Fig. 2). At the lower concentration of IFN (20 ng/ml; InM), p70 appeared to be induced less effectively in cultures supplied with rbTP-1 than with rbolFN- $\alpha_{\mathrm{I}} 1$, compared with control cultures (Fig. 2a). 
Table 2. Effects of interferons recombinant bovine trophoblast protein-1 (rbTP-1) and recombinant bovine interferon- $\alpha_{1} 1$ (rboIFN- $\left.\alpha_{1} 1\right)$ on incorporation of $\mathrm{L}-\left[{ }^{3} \mathrm{H}\right]$ leucine into proteins released into the medium by cultured endometrial explants

\begin{tabular}{lccc}
\hline Treatment & $\begin{array}{c}\text { Concentration of IFN } \\
\text { added to medium } \\
(\mathrm{ng} / \mathrm{ml})\end{array}$ & $\begin{array}{c}\text { Protein } \\
\text { in medium* } \\
(\mathrm{mg} / \mathrm{ml})\end{array}$ & $\begin{array}{c}\text { Radioactivity } \\
\text { incorporated } \\
\left(\text { d.p.m. } \times 10^{-7}\right)\end{array}$ \\
\hline Control & - & $0 \cdot 74 \pm 0.02(5)$ & $1 \cdot 89 \pm 0.35(5)$ \\
rbTP-1 & 20 & $0.68 \pm 0.05(4)$ & $2 \cdot 07 \pm 0.20(4)$ \\
rbTP-1 & 200 & $0.67 \pm 0.05(4)$ & $2 \cdot 25 \pm 0.37(4)$ \\
rboIFN- $\alpha_{1} 1$ & 20 & $0.69 \pm 0.03(4)$ & $1.70 \pm 0.46(4)$ \\
rboIFN $\alpha_{1} 1$ & 200 & $0.69 \pm 0.09(4)$ & $1.51 \pm 0.42(4)$ \\
\hline
\end{tabular}

Endometrial explants were cultured as described in the Methods. Explant tissues were derived from the vehicle-injected ewes also used for data in Table 1.

*Data are average values \pm s.e.m. (with numbers of ewes in parentheses). No significant differences $(P>0 \cdot 1)$ were observed between treatments. The ewes used in this study were at Day 13 of their oestrous cycles.

\section{Discussion}

These experiments confirm that a recombinant $\alpha_{1}$ interferon (rbolFN- $\left.\alpha_{1} 1\right)$ and the longer (172 residue vs. 166) recombinant bTP-1 can, like oTP-1 (Salamonsen et al., 1988; Silcox et al., 1988), induce p70 synthesis by endometrial tissue derived from ewes in the mid-luteal phase of their oestrous cycles. The effects of rbTP- 1 and rboIFN- $\alpha_{1} 1$ were comparable when they were supplied in vitro at $10 \mathrm{~nm}$, but the latter seemed more potent at $1 \mathrm{~nm}$. One explanation is that the binding constants of rbTP-1 and rbolFN- $\alpha_{1} 1$ for the Type 1 IFN receptor, which is abundant in endometrium (Hansen et al., 1989; Knickerbocker \& Niswender, 1989), differ. Alternatively, even though the rbTP-1 and rboIFN- $\alpha_{1} 1$ had comparable antiviral activity initially (Klemann et al., 1990), the rbTP-1 may be less stable and hence less effective over the 24-h culture period. Whatever the explanation, it is evident from this and experiments performed earlier that a range of different IFN. $\alpha$ can induce $p 70$ synthesis and that this protein provides a sensitive and useful marker for IFN action on uterine endometrial tissue (Silcox et al., 1988, Sharif et al., 1989). It remains to be determined whether this protein plays any role in maternal recognition of pregnancy in ewes. It is also unclear whether it is secreted towards the uterine lumen in vivo.

Expt 1 demonstrated that when rboIFN- $\alpha_{1} 1$ was injected into ewes at a comparable time after oestrus and at doses identical to those shown to improve pregnancy rates in bred ewes (Nephew et al., 1990; Schalue-Francis et al., 1991), there was a pronounced effect on the synthesis of p70 by the endometrium of both uterine horns. Therefore, it would not be unreasonable to expect other aspects of uterine biochemical activity, such as prostaglandin metabolism (Salamonsen, 1988; Helmer et al., 1989), oxytocin receptor synthesis (Bazer et al., 1991) or turnover of second messengers (Mirando et al., 1990) to be similarly affected throughout the endometrium. The antiviral activity of rboIFN- $\alpha_{1} 1$ in the blood of ewes following a $2 \cdot 0-\mathrm{mg}$ injection rises to a maximum of $\sim 500$ International Reference Units (IRU) within $2 \mathrm{~h}$ and then falls to $\sim 200 \mathrm{units} / \mathrm{ml}$ prior to the next injection $12 \mathrm{~h}$ later (Schalue-Francis et al., 1991). Since the IFN had an activity of $\sim 5 \times 10^{7}$ IRU/mg the concentration of active IFN in the circulation would range between about $0.5 \mathrm{~nm}$ and $0.2 \mathrm{~nm}$ during the $2 \frac{1}{2}$-day experiment. Although these concentrations are low, they are still above the $\mathrm{K}_{\mathrm{D}}$ of the rboIFN- $\alpha_{1} 1$ for the Type 1 ovine IFN receptor, which is probably $\sim 10^{-11} \mathrm{M}$ (Hansen et al., 1989; Knickerbocker \& Niswender, 1989). The amount of p70 produced by these cultures from injected ewes appeared greater than that from the explants which had only been exposed to IFN in culture, and was comparable to $\mathrm{p} 70$ production observed with tissue from pregnant ewes (Sharif et al., 1989). This difference may relate to the time required for full induction of $\mathrm{p} 70$ in vitro. The effect was noted in both uterine horns, whereas in pregnancy the oTP-1 
produced by the conceptus has a local action confined to regions of endometrium in contact with trophoblast (Sharif et al., 1989).

We thank K. Kramer, J. Cross, T. Hansen and W. Trout for help with surgeries, T. SchalueFrancis for assistance with injections and sample preparation and $\mathrm{G}$. Foristal for preparing the manuscript. The research was supported by NIH grant HD21896. This paper is Journal series number 11269 from the Missouri Agriculture Experiment Station.

\section{References}

Bartol, F.F., Roberts, R.M., Bazer, F.W., Lewis, G.S., Godkin, J.D. \& Thatcher, W.W. (1985) Characterization of proteins produced in vitro by peri-attachment bovine conceptuses. Biol. Reprod. 32, 681-694.

Bazer, F.W., Vallet, J.L., Roberts, R.M., Sharp, D.C. \& Thatcher, W.W. (1986) Role of conceptus secretory products in establishment of pregnancy. J. Reprod. Fert. 76, 841-850.

Bazer, F.W., Thatcher, W.W., Hansen, P.J., Mirando, M.A., Ott, T.L. \& Plante, C. (1991) Physiological mechanisms of pregnancy recognition in ruminants. J. Reprod. Fert. Suppl. 43, 39-47.

Capon, D.J., Shepard, H.M. \& Goeddel, D.V. (1985) Two distinct families of human and bovine interferon- $\alpha$ genes are coordinately expressed and encode functional polypeptides. Mol. Cell. Biol. 5, 768-779.

Godkin, J. D., Bazer, F.W., Moffatt, J., Sessions, F. \& Roberts, R.M. (1982) Purification and properties of a major, low molecular weight protein released by the trophoblast of sheep blastocysts at Day 13-21.J. Reprod. Fert. 65, 141-150.

Godkin, J.D., Bazer, F.W. \& Roberts, R.M. (1984) Ovine trophoblast protein 1 , an early secreted blastocyst protein, binds specifically to uterine endometrium and affects protein synthesis. Endocrinology 114, 120-130.

Hansen, P.J., Anthony, R.V., Bazer, F.W., Baumbach, G.A. \& Roberts, R.M. (1985) In vitro synthesis and secretion of ovine trophoblast protein-1 during the period of maternal recognition of pregnancy. Endocrinology 117, 1424-1430.

Hansen, T.R., Kazemi, M., Keisler, D.H., Malathy, P.V., Imakawa, K. \& Roberts, R.M. (1989) Complex binding of the embryonic interferon, ovine trophoblast protein-1, to endometrial receptors. J. Interferon Res. 9, 215-225.

Helmer, S.D., Gross, T.S., Hansen, P.J. \& Thatcher, W.W. (1989) Bovine trophoblast protein-1 complex alters endometrial protein and prostaglandin secretion and induces an intracellular inhibitor of prostaglandin synthesis in vitro. J. Reprod. Fert. 87, $421-430$.

Klemann, S.W., Li, J., Imakawa, K., Cross, J.C., Francis, H. \& Roberts, R.M. (1990) The production, purification and bioactivity of bovine trophoblast protein-1 (bovine trophoblast interferon). Mol. Endocr. 4, 1506-1514.

Knickerbocker, J.J. \& Niswender, G.D. (1989) Characterization of endometrial receptors for ovine trophoblast protein-1 during the estrous cycle and early pregnancy in sheep. Biol. Reprod. 40, 361-369.

Mirando, M.A., Ott, T.L., Vallet, J.L., Davis, M. \&
Bazer, F.W. (1990) Oxytocin-stimulated inositol phosphate turnover in endometrium of ewes is influenced by stage of the estrous cycle, pregnancy, and intrauterine infusion of ovine conceptus secretory proteins. Biol. Reprod. 42, 98-105.

Nephew, K.P., McLure, K.E., Day, M.L., Xie, S., Roberts, R.M. \& Pope, W.F. (1990) Effects of intramuscular administration of recombinant bovine interferon-alpha 1 during the period of maternal recognition of pregnancy, J. Anim. Sci. 68, 27662770.

Plante, C., Hansen, P.J., Martinod, S., Siegenthaler, B., Thatcher, W.W. \& Leslie, M.V. (1989) Effect of intrauterine and intramuscular administration of recombinant bovine interferon $\alpha 1$ on luteal lifespan in cattle. J. Dairy Sci. 72, 1859-1865.

Roberts, R.M., Baumbach, G.A., Buhi, W.C., Denny, J.B., Fitzgerald, L.A., Babelyn, S.F. \& Horst M.N. (1984) Analysis of membrane polypeptides of two dimensional polyacrylamide gel electrophoresis. In Molecular and Chemical Characterization of Receptors, pp. 61-113. Eds C. J. Venter \& L. C. Harrison. Alan R. Liss, New York.

Roberts, R.M. (1989) Minireview: conceptus interferons and maternal recognition of pregnancy. Biol. Reprod. 40, 449-452.

Roberts, R.M., Farin, C.E. \& Cross, J.C. (1990a) Trophoblast proteins and maternal recognition of pregnancy. In Oxford Reviews of Reproductive Bio$\log y$, vol. 12, pp. 147-180. Ed. S. Milligan. Oxford University Press, Oxford.

Roberts, R.M., Schalue-Francis, T., Francis, H. \& Keisler, D. (1990b) Maternal recognition of pregnancy and embryonic loss. Theriogenology 33, $175-183$.

SAS (1985) SAS User's Guide: Statistics. SAS Institute Inc., Cary, NC.

Salamonsen, L.A., Stuchbery, S.J., O'Grady, C.H., Godkin, J.D. \& Findlay, J.K. (1988) Interferon-alpha mimics effects of ovine trophoblast protein-1 on prostaglandin and protein secretion by ovine endometrial cells in vitro. J. Endocr. 117, R1-R4.

Schalue-Francis, T.K., Farin, P.W., Cross, J.C., Keisler, D. \& Roberts, R.M. (1991) Effect of injected bovine interferon- $a_{1} 1$ on oestrous cycle length and pregnancy success in sheep. J. Reprod. Fert. 91, 347-356.

Sharif, S.F., Francis, H., Keisler, D.H. \& Roberts, R.M. (1989) Correlation between the release of ovine trophoblast protein-I by the conceptus and the production of polypeptides by the maternal endometrium of ewes. J. Reprod. Fert. 85, 471-476.

Silcox, R.W., Francis, H. \& Roberts, R.M. (1988) The 
effects of ovine trophoblast protein-1 (oTP-1) on ovine endometrial protein synthesis are mimicked by human alpha-1 interferon. J. Anim. Sci. 66 (Suppl. 1), 153-154.

Vallet, J.L., Bazer, F.W. \& Roberts, R.M. (1987) The effect of ovine trophoblast protein-1 on endometrial protein secretion and cyclic nucleotides. Biol. Reprod. 37, 1307-1316.
Zarco, L., Stabenfeldt, G.H., Basu, S., Bradford, G.E. \& Kindahl, H. (1988) Modification of prostaglandin F-2a synthesis and release in the ewe during the initial establishment of pregnancy. J. Reprod. Fert. 83, 527-536.

Received 10 September 1990 